\title{
As camadas de Tschumi: uma breve análise de influências gráficas de Bernard Tschumi
}

Luiza Paes de Barros Camara de Lucia Beltramini

Paulo César Castral

Abstract

Presente artigo tem como objetivo analisar algumas influências gráficas do arquiteto franco-suíço BernardTschumi. Através de análise de entrevistas realizadas com o arquiteto observou-se a presença de alguns personagens que foram analisados e desta forma a influência gráfica foi reconhecida. São apresentados, de forma sucinta, três grandes influências do arquiteto que se relacionam diretamente com a elaboração das Notações Arquitetônicas desenvolvidas por Tschumi na década de 1970. As notações arquitetônicas analisam o movimento os usuários nos espaços propostos pela arquitetura e compõem a atual pesquisa dos autores.

\section{Palavra-chaves}

BernardTschumi, desenho, influência gráfica, notação arquitetônica, Parque La Villette.
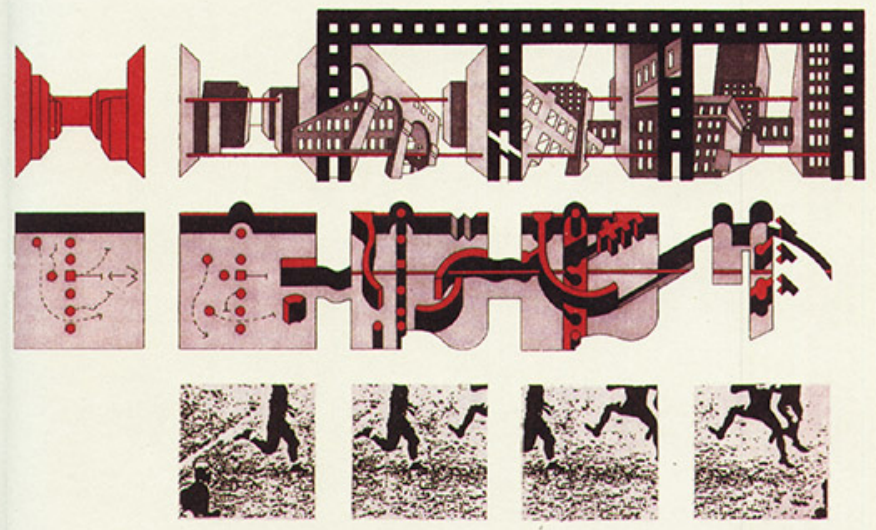
Antes da invenção da câmera fotográfica a retratação dos locais, pessoas e cerimônias eram realizadas através de pinturas e desenhos. Para a arquitetura, porém, o desenho tem um papel a mais que o de apenas representar o que existe, o desenho representa algo que pode vir a existir. A arquitetura é construída a partir de uma demanda e passa por diversos estágios de croquis, desenhos e registros. Os desenhos se mantiveram na arquitetura e na construção civil como uma ferramenta que auxilia a construção dos edifícios. A etapa de desenho, de concepção, é necessária para prever problemas, dificuldades construtivas, compatibilização de projetos complementares e, inicialmente, a concepção espacial do programa. $\bigcirc$ desenho, portanto era algo pertencente à arquitetura antes da arquitetura existir. Após a concepção e a construção da arquitetura vem à fase de ocupação do espaço. Obviamente que essa ocupação depende do programa, da cultura local e dos limites estabelecidos para os usuários. Olhando o panorama da arquitetura que era produzida no início dos anos 1970 o arquiteto franco-suíço BernardTschumi (1944) se perguntava constantemente sobre como a arquitetura e as cidades poderiam ser um gatilho para a mudança social e política, dessa forma seus estudos sobre o comportamento das pessoas e a influencia destas na arquitetura e vice-versa acabaram the rendendo importantes trabalhos, dentre os quais são destacados o Architecture and Disjunction (1996) e o The Manhattan Transcripts ( 198I). O primeiro reúne textos de Tschumi produzidos entre 1975 e 1990 e o segundo é composto por "quatro exposições contendo notações experimentais de situações arquiteturais" [Sperling 201 I, p. 219].

O papel passivo dos usuários na arquitetura foi algo que gerou uma reflexão no arquiteto suíço Bernard Tschumi. Em sua obra Architecture and Disjunction (1996) o autor afirma que "não existe arquitetura sem programa, sem ação, sem evento" [Tschumi, 1996, p. 3], junto com muitos arquitetos da sua geração, por volta de 1968, Tschumi estava preocupado com o papel do arquiteto na sociedade e nas mudanças políticas e sociais que poderiam resultar da prática arquitetônica.

Tschumi questiona a relação entre a arquitetura e o programa, ou seja, entre o uso e o espaço e como um afeta o outro para ele "a materialidade do [...] corpo coincide e luta com a materialidade do espaço. [O] corpo carrega em si propriedades e determinações espaciais: em cima, em baixo, direita, esquerda, simetria, dissimetria. Ouve tanto quanto vê" [Tschumi 1996, p. 39].

O novo termo estabelecido pelo arquiteto suíço nos Manhattan Transcripts, Notação Arquitetônica, é a ideia de que a arquitetura está ligada diretamente com o evento e com o programa, dessa forma "o arquiteto traz, em seus projetos, os interesses programáticos e formais dentro do discurso arquitetônico e da sua representação" [Padovano 200 I]. Para Tschumi o arquiteto não apenas compõem formas, ele também traz em seus projetos "os

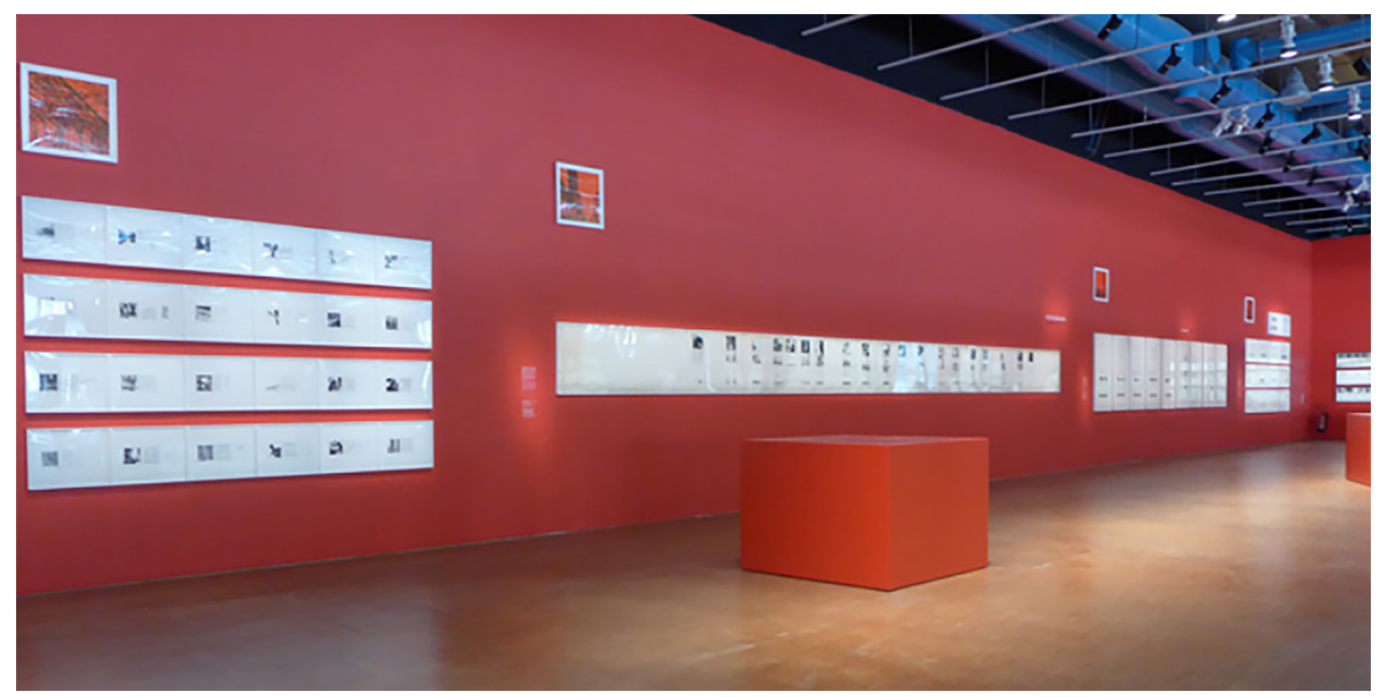


interesses programáticos e formais dentro do discurso arquitetônico e de sua representação" [Padovano 200 I].

Não se sabe se Tschumi teve contato com outro conjunto de notações elaborado pelo arquiteto americano Philip Thiel (1920-2014) que também questionavam o movimento das pessoas nos espaços. As notações de Thiel são focadas em questões fenomenológicas enquanto que as de Tschumi tem o programa como tema principal. A leitura de Tschumi sobre arquitetura faz com que ela deixe de ser apenas uma polarização de forma-função, objeto material-conceito, e passa a ser mais do que esses dois polos juntos. A Notação Arquitetônica é uma compreensão física e conceitual do lugar edificado. Esse novo conceito se estrutura como os Elementos de Composição," composto por três níveis de representação: a do espaço, a do movimento e a do evento" [Solfa 2008], em entrevista à Dwyre (20I4, pg. 13), Tschumi declara que "não existe arquitetura sem movimento". De forma bem resumida, de acordo com Saygin (20 | 8), o espaço corresponde à concepção dos arquitetos, o evento à percepção dos usuários e o movimento a experiência desses.

"Apesar de que nenhum modo de notação [...], possa transcrever a grande complexidade do fenômeno arquitetônico, o progresso da notação arquitetônica é vinculado à renovação tanto da arquitetura quanto dos seus conceitos de cultura associados" [Fracalossi 20 I 2].

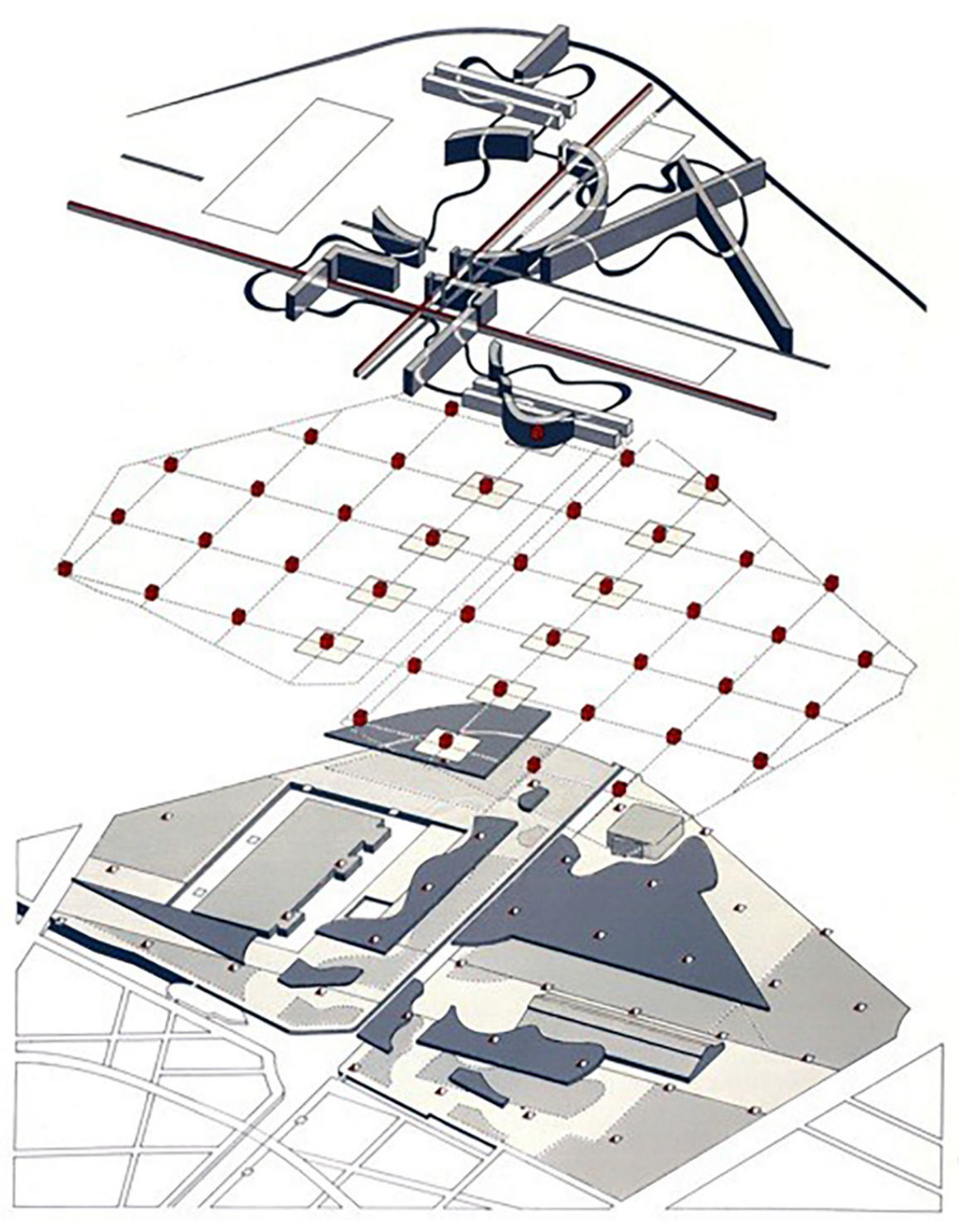


Através da tripartição que compõem o termo cunhado porTschumi ele tenta demonstrar que a arquitetura demanda uma leitura complexa. $\bigcirc$ espaço não pode ser apenas espaço ele tem que ser lido juntamente, e principalmente, com o tempo. Afinal o que é espaço arquitetonicamente falando? Em Disjunction and Architeture (1996) essa questão é respondida da seguinte forma: "para definir espaço (para fazer espaço distinto) significa literalmente 'determinar fronteiras'" [Tschumi 1996, p. 30]. O objetivo do modo tripartido que compõem o termo é introduzir na arquitetura "a ordem da experiência, a ordem do tempo - movimentos, intervalos, sequências - visto que tudo inevitavelmente intervém na leitura" [Tschumi 1994 apud Solfa 2008, p. I I].

As notações retratando os eventos em Manhattan não são desenhos arquitetônicos, eles não são projeções ortogonais, nem tão pouco desenhos perspectivos. Ao mesmo tempo eles não podem ser categorizados como meras fantasias, elas transcrevem uma realidade arquitetônica interpretada pelo autor. $\bigcirc$ objetivo dessas ditas transcrições é evidencias coisas que normalmente são removidas das representações arquitetônicas convencionais como a complexa relação entre os espaços e seus usos, entre os objetos e os eventos.

Em entrevista a Alonso [Bernard 20I4] Tschmi afirma que somos prisioneiros de uma parte da nossa biografia que não podemos mudar e isso é quando nascemos e como herança dessa parte imutável de nossa história está o momento que o mundo passa naquele momento. No momento em que Tschumi nasce em 1944 em Laussane na Suiça o filme e a política eram muito importante, assim como a internet é atualmente. A influencia da sétima arte é tão clara no trabalho de Tschumi que ao traduzir as Notações arquitetônicas presentes nos Manhattans Transcripts se deparou, dentre outros produtos, com um desenho de 32 pés - 9,75 m - representando uma caminhada pela Rua 42 de Manhattan (ver figura I). Apesar de The Manhattan Transcripts ter 'lançado'Tschumi academicamente e teoricamente foi o parque francês LaVillete (ver figuras 2) que o coloca no circuito mundial de arquitetos. O concurso promovido pelo governo da França em I 982- I 983 previa um parque onde antes havia sido um grande matadouro que funcionou entre os séculos $X I X$ e $X X[$ Comber

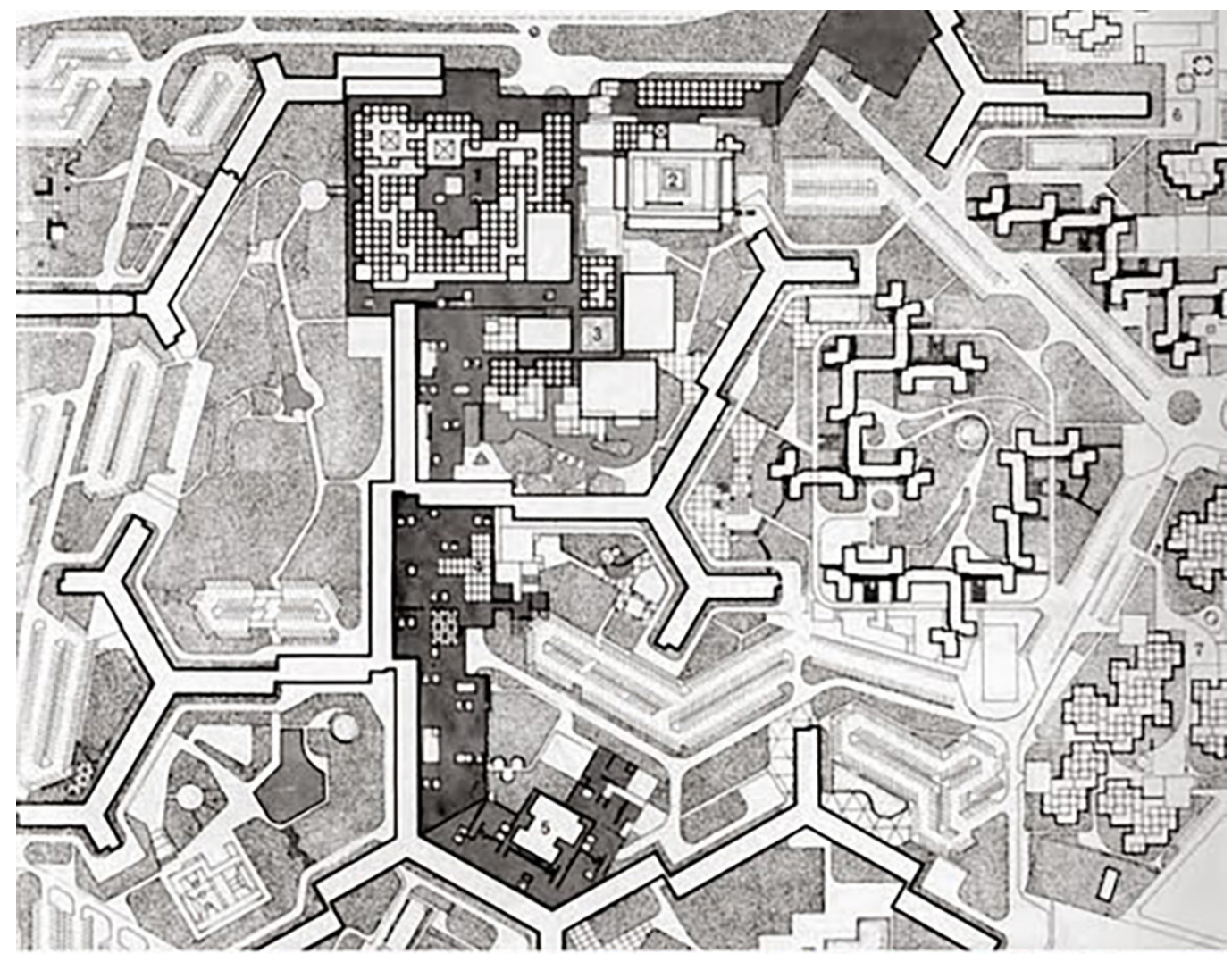


20 I8]. O parque que se baseia em sistemas estabelecidos por Tschumi através de pontos, linhas e planos ortogonais, o único caminho sinuoso de acordo com Guatelli (20l7) é "o caminho 'cinemático' [...] uma homenagem de Tschumi ao cimena, à arte do movimento". Outras influências dos traçados elaborados por Bernard que puderam ser identificados ao longo de sua carreira Derek Reddington, Cedric Price e os três arquitetos que compuseram o escritório Candilis-Josic-Woods.

Começando pelos últimos citados, os três arquitetos - George Candillis (1913-1995), Shadrach Woods (1923-1973) e Alexis Josic (1921-201 I) - foram patrões de Tschumi que estagiou com eles por algum tempo em Paris. Semelhante aos traçados proposto porTschumi podemos identificar dois projetos de seus antigos chefes o Le Mirail (1962) localizado em Toulouse, França (ver figura 2).

O projeto foi alvo de concurso e propôs a criação de diferentes densidades para um bairro de, aproximadamente, 100.000 habitantes. $O$ desenho apresentado, apesar de muito mais ortogonal em seus edifícios também estabelece caminhos e divisões como o apresentado no concurso vencido por Bernard.

A segunda referência Cedric Price (1934-2003) também o influenciou ainda quando estudante, se observarmos um dos mais relevantes projetos de Price conhecido como Fun Place (ver figura 4) e a tese desenvolvida porTschmi (ver figura 5) observamos a influência direta do traçado de um pro outro.

Fig. 4. Croqui do Projeto Fun Palace de Cedric Price [Glynn 2005].

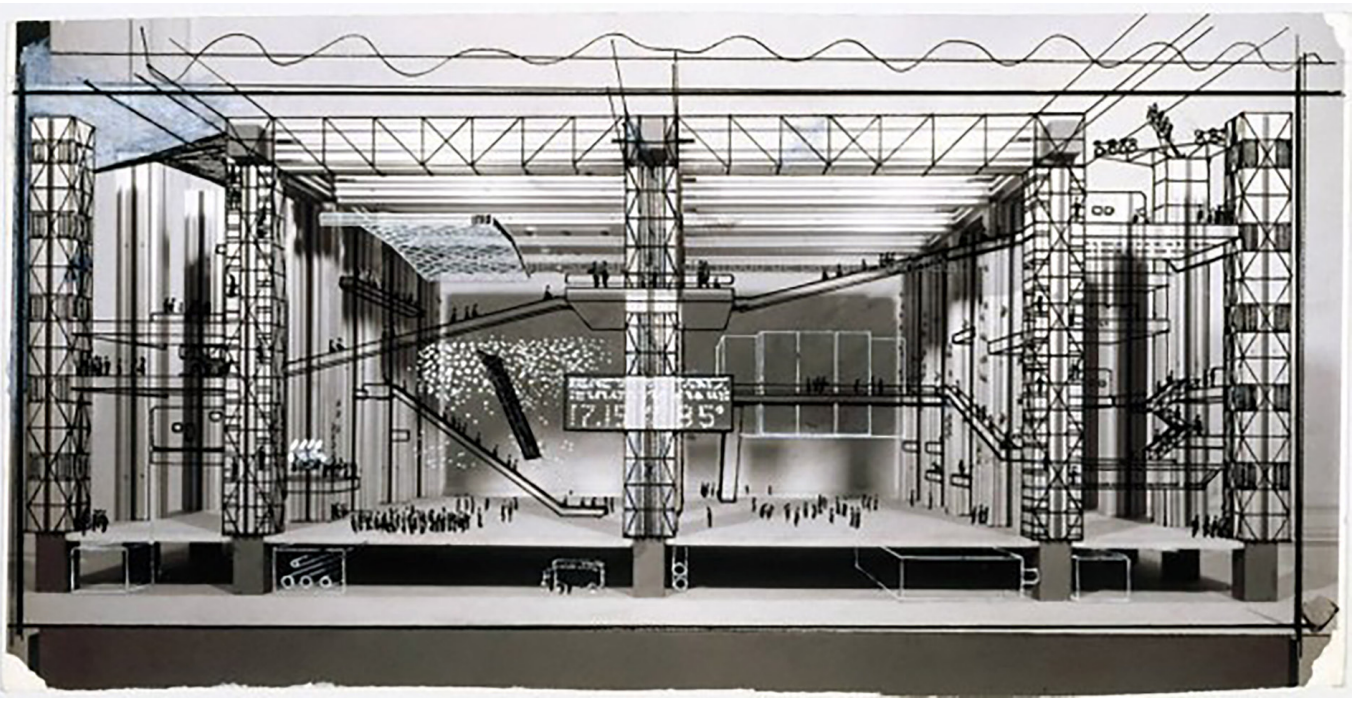

Cedric tinha como centro de seus proetos a ideia de flexibilidade permanente, para ele os prédios deveriam servir sempre a um propósito e que não deveriam nunca ser demolidos e sim modificados para novos usos. Apesar de Tschumi nunca ter executado o projeto apresentado em sua tese, o Fun Place de Cedric gerou frutos e é uma clara influencia do que hoje é o Centro George Pompidou em Paris.

Como ultima influência listada está alguém que influencia Tschumi numa fase posterior a sua formação acadêmica. Dereck Revington é um recém-formado que participa da exposição organizada por Tschumi em 1975 em Nova lorque chamada "A space: a Thousand Words" [Bernard 2017]. Na ocasião os convidados deveriam escolher uma imagem que representasse o que era espaço pra eles e que complementassem as informações com mil palavras. Revington escolhe como imagem a planta de um armazém abandonado em Londres onde ele faz uma intervenção. Caminhando pelo lugar ele registra os movimentos e os percursos percorridos gerando uma definição do espaço demarcada em giz no chão (ver figura 6). A semelhança do que é apresentado por Revington e o projeto vencedor do parque parisiense projetado porTschumi é inegável. 
Fig. 5. Imagem da tese de Bernard Tschumi [Tschumi 2013].
Fig. 6. Planta baixa dos movimentos realizados por Dereck Revington [Cook 1983].

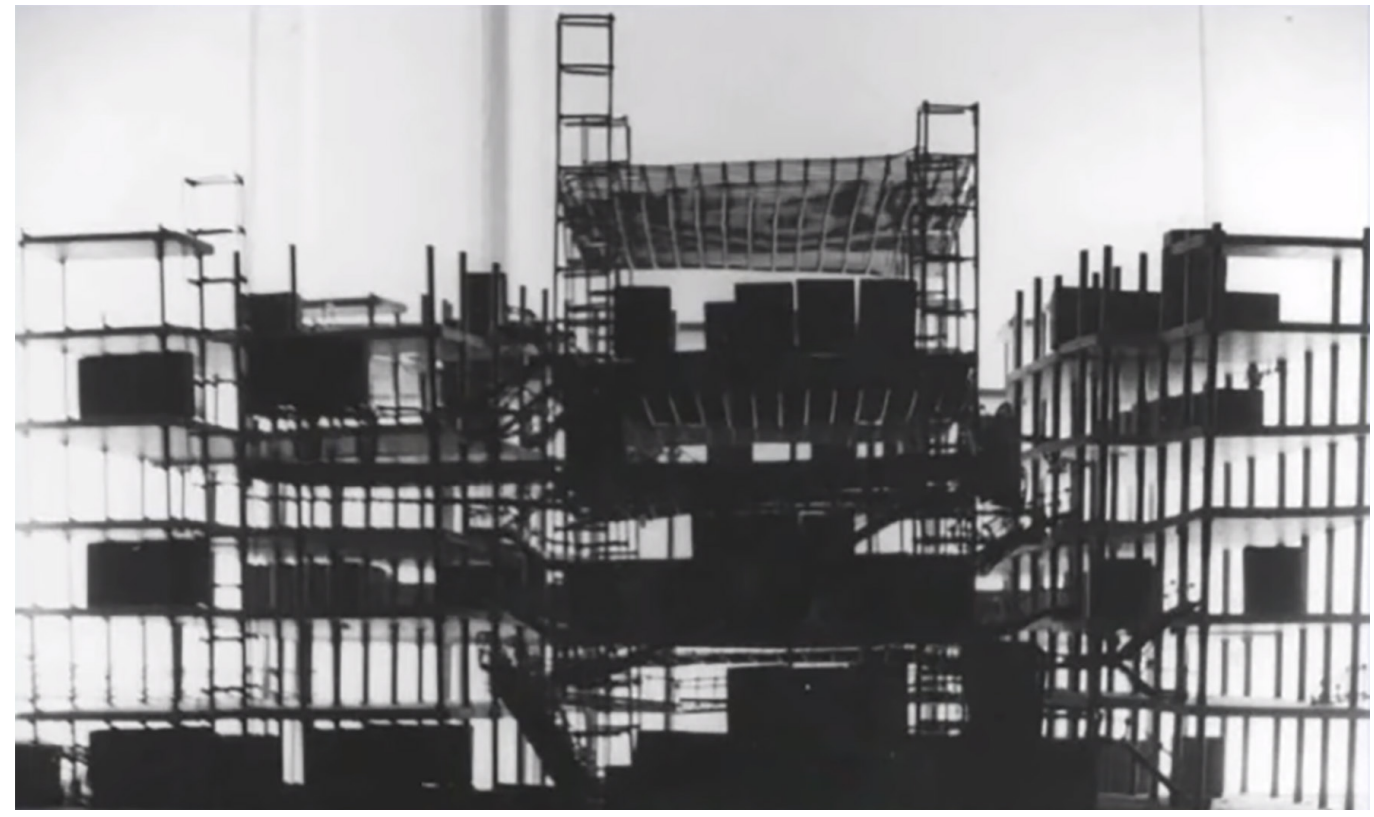

\section{Conclusão}

A história do desenho se confunde com a história da arquitetura, nesse pequeno recorte de tempo e de atores observamos que Bernard se permite influencia por personagens que contribuíram ativamente para que o desenho evoluísse e se reinventa junto com a humanidade, suas demandas e suas inovações. Tschumi consegue recolher essas fontes todas e transforma-las em um dos aspectos mais interessantes da arquitetura contemporânea, a Notação Arquitetônica, estudando o espaço, sua apropriação e suas dinâmicas através do movimento e apresentando os resultados através de desenhos e concretizando muito deles no parque La Villette. Os frutos gráficos da análise sob a ótica de notação arquitetônica registram os movimentos de tal forma que se assemelham a grandes roteiros de filmes.

É possível notar que o La Villete traz em suas propostas também influencias desses três personagens identificados. A variação de densidades proposta por Candillis, Woods e Josic pode ser vista na distribuição dos equipamentos no parque. A adaptabilidade defendida por Price se dá de forma ampla ao permitir que os usuários usufruam os equipamentos ou, se concordarmos com Kenneth Michael Hays [Tschumi 20I3], dos 'eventos' presentes no parque. E a transformação de um lugar em espaço através da apropriação e do percurso como demonstrado por Revington num prelúdio do que viria a ser a Notação Arquitetônica. A reinvenção da análise que a notação propõe resgata o desenho numa era onde os computadores já ganhavam território e até hoje segue como uma inovadora chave de leitura dos espaços construídos.
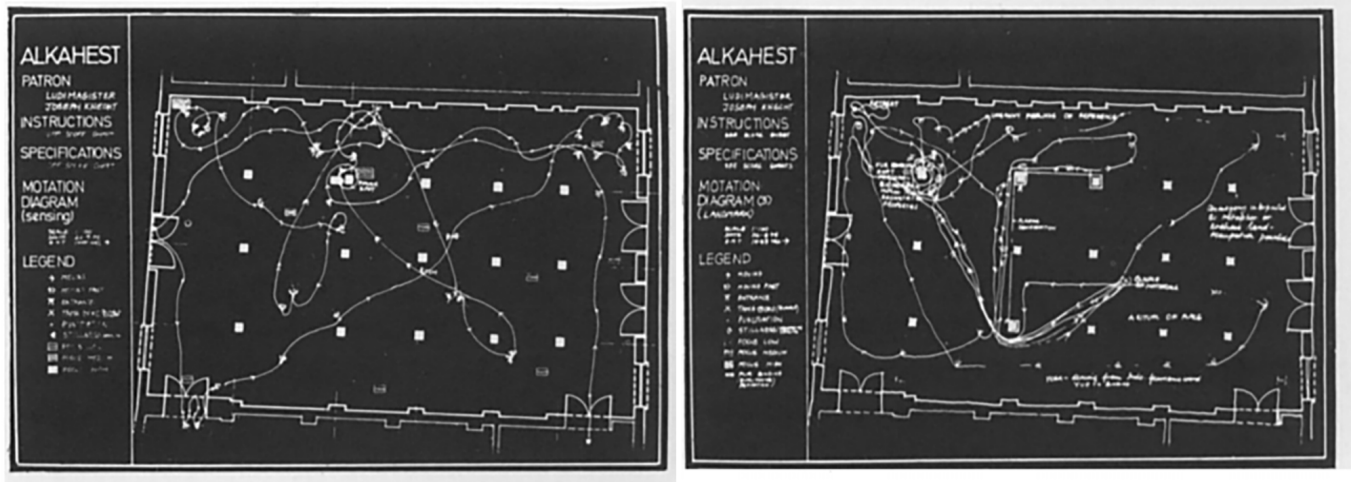


\section{Referências bibliográficas}

Comberg E. (20 I 8). Como o Parc de la Villette influenciou a maneira como projetamos nossos parques no século XXI [How the Parc de la Villette Kickstarted a New Era for Urban Design] 23 Ago ArchDaily Brasil. (Trad. Libardoni, Vinicius) <https:// www.archdaily.com.br/br/900296/como-o-parc-de-la-villette-influenciou-a-maneira-como-projetamos-nossos-parques-no-seculo-Xxi>

Cook Peter (1983). Strange pavilions of the mind. The Work of Diploma Unit 10, 1973-1983. In AA Files, (4), pp. I02-107: <em www.jstor.org/stable/29543369>

Dwyre Cathryn, Perry Chris \& Tschumi Bernard (2014). Architecture Beyond Architecture. In PAJ: A journal of Performance and Art, 37(I), pp. 8- I5: <https://doi.org/10.1 | 62/PAJ__a_0023|>.

Fracalossi Igor (2019). "Disjunções / Bernard Tschumi” 26 Abr 2012. ArchDaily Brasil: <https://www.archdaily.com.br/45675/ disjuncoes-bernard-tschumi>.

Glynn Ruairi (2005). Fun Palace - Cedric Price. Interactive Architecture. 19 out 2005: <http://wwwinteractivearchitecture.org/ fun-palace-cedric-price.html. Acessado em 12 jan 2020>.

Graham Foundation (2008). Graham foundation, 2008: <http://www.grahamfoundation.org/grantees/5 I80-bernard-tschumi-concept-and-notation Acesso em 14 fev. 2020>

Guatelli Igor (2017). Edificar parques. O [parergonal] Parc de La Villette e o futuro do passado. In A quitextos, São Paulo, ano I8, n. 208.01,Vitruvius, set. 2017: <https://www.vitruvius.com.br/revistas/read/arquitextos/|8.208/67/5>

Padovano Bruno Roberto (200 I). Bernard Tschumi. Entrevista, São Paulo, ano 02, n. 008.0 I, Vitruvius, out. 200 I:<http://www. vitruvius.com.br/revistas/read/entrevista/02.008/3344>.

Papillault Rémi (2020). Planejamento em seção: <https://planejamentoemsecao.wordpress.com/casos-de-estudo/50s-60s/ le-mirail-candilis/>

Saygin Salgirli (2018). Radicalizing Premodern Space: A Perspective from the Late Medieval Ottoman World. In Radical History Review. I' January 20 I8; 2018 (130), pp. 45-6I. doi: https://doi.org/I0.1215/01636545-42I7889

Solfa Marilia, Serra Richard,Tschumi Bernard (2008). Richard Serra e Bernard Tschumi:.Anais do II Seminário Arte e Cidade: Cultura, memória e contemporaneidade, p. 21, 2008; <https://www.academia.edu/19872921/_Richard_Serra_e Bernard Tschumi_arte_e_arquitetura_voltadas_para_a_constituição_e_percepção_do_espaço_urbano_?auto=download>.

Souza Abelardo de (20।3). E. Clássicos da Arquitetura: Parc de la Villette / Bernard Tschumi [AD Classics: Parc de la Villette / Bernard Tschumi Architects] 21 Dez 2013. ArchDaily Brasil: <https://www.archdaily.com.br/ |604 I 9/classicos-da-arquitetura-parc-de-la-villette-slash-bernard-tschumi>

Sperling D. Moreno. (FAU/USP). (20I I). Manhattan Transcripts Desdobrado - A Arquitetura Parametrizada pelos Eventos. In Cadernos de pós-graduação em arquitetura e urbanismo, Dezembro 20 I I, p. 809, 20 I l: <https://www.researchgate.net/publication/2363|2458_Manhattan_Transcripts_Desdobrado_-_A_Arquitetura_Parametrizada_pelos_Eventos>.

Tschumi Bernard (1978). Part I of 2. Los Angeles, EUA: Southern California Institute of Architecture, 20 I7: <https://www. youtube.com/watch? $v=7$ MMIEitAofM>

Tschumi Bernard (1996). Architecture and Disjunction. Cambridge, Massachusets: The MIT Press.

Tschumi Bernard (2013). Palestra proferida na Escola de Graduação em Design da Universidade de Harvard (Massachusetts): $<$ https://www.youtube.com/watch?v=nJ4RIYkJ_v0>

Tschumi Bernard (20|4). Interview. Direção: Phineas Harper.Veneza:The Architectural Review: <https://www.youtube.com/ watch? $=$ Dac_IIP5Dc0>

\section{Autores}

Luiza Paes de Barros Camara de Lucia Beltramini, Univeraity of São Paulo, luiza.beltramini@usp.br

Paulo César Castral, Univeraity of São Paulo, pcastral@usp.br

Para citar este capítulo: Paes de Barros Camara de Lucia Beltramini Luiza, Castral César Paulo (2020). As camadas de Tschumi: uma breve análise de influências gráficas de Bernard Tschumi/Tschumi's layers: a brief analysis of Bernard Tschumi's graphic influences. In Arena A., Arena M., Brandolino R.G., Colistra D., Ginex G., Mediati D., Nucifora S., Raffa P. (a cura di). Connettere. Un disegno per annodare e tessere. Atti del $42^{\circ}$ Convegno Internazionale dei Docenti delle Discipline della Rappresentazione/Connecting. Drawing for weaving relationships. Proceedings of the 42th Internationa Conference of Representation Disciplines Teachers. Milano: FrancoAngeli, pp. 698-7I I. 


\section{Tschumi's Layers: a Brief Analysis of Bernard Tschumi's Graphic Influences}

Luiza Paes de Barros Camara de Lucia Beltramini Paulo César Castral

\section{Abstract}

This article aims to analyze some visual influences of the Franco-Swiss architect Bernard Tschumi. Through the study of interviews carried out with the architect, the presence of some characters that were analyzed was observed, and in this way, the graphic influence was recognized. Three significant influences of the architect are presented succinctly, which are directly related to the elaboration of Architectural Notations developed by Tschumi in the 1970s. Architectural notations analyze the movement of users in the spaces proposed by architecture and compose the authors' current research.

Keywords

Bernard Tschumi, drawing, graphic influence, architectural notation, Parque La Villette.
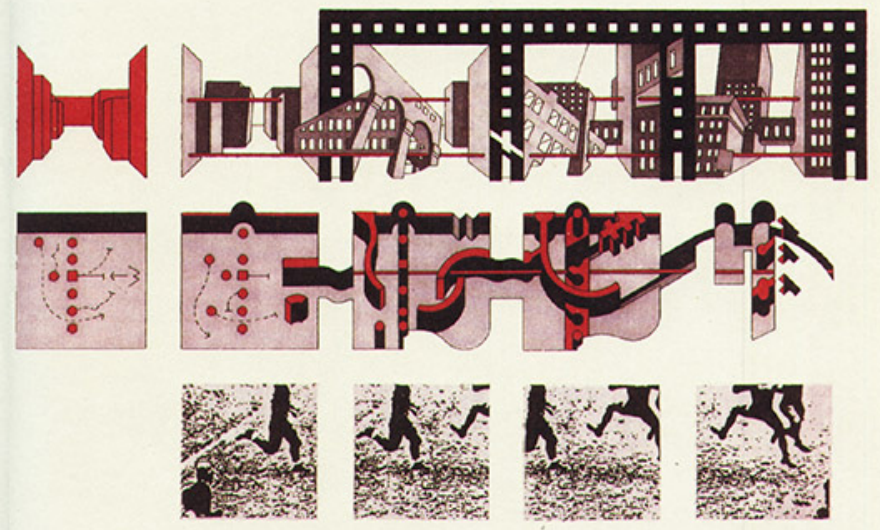
Before the invention of the photographic camera, portraits of places, people, and ceremonies were performed through paintings and drawings. For architecture, however, drawing has a role more than just representing what exists; drawing represents something that may come to exist. The architecture is built on demand and goes through several stages of sketches, drawings, and records. The drawings remained in architecture and civil construction as a tool that helps the construction of buildings. The design stage, of conception, is necessary to foresee problems, constructive difficulties, compatibility of complementary projects, and, initially, the spatial design of the program. Draw, therefore, was something that belonged to architecture before architecture existed.

After the design and construction of the architecture, it comes to the space occupation phase. This occupation depends on the program, the local culture, and the limits established for users. Looking at the panorama of architecture that was produced in the early 1970s, the Franco-Swiss architect Bernard Tschumi (1944) asked himself always about how architecture and cities could be a trigger for social and political change; thus his studies on the people's behavior and their influence on architecture and vice versa ended up giving him essential works, among which Architecture and Disjunction (1996) and The Manhattan Transcripts (198I). The first brings together texts by Tschumi produced between 1975 and 1990, and the second consists of "four exhibitions containing experimental notations of architectural situations" [Sperling 201 I, p. 219].

The passive role of users in architecture was something that generated a reflection in the Swiss architect Bernard Tschumi. In his work Architecture and Disjunction (1996) the author states that "there is no architecture without a program, without action, without an event" [Tschumi 1996, p. 3], together with many architects of his generation, around I968, Tschumi he was concerned with the role of the architect in society and the political and social changes that could result from architectural practice.

Tschumi questions the relationship between architecture and the program, that is, between use and space and how one affects the other for him "the materiality of the body [...] coincides and struggles with the materiality of space. [The] body carries spatial properties and determinations: top, bottom, right, left, symmetry, dissymmetry. Listen as much as you see" [Tschumi 1996, p. 39].

The new term established by the Swiss architect in Manhattan Transcripts, Architectural Notation, is the idea that architecture is linked to the event and the program, thus "the architect brings, in his projects, the programmatic and formal interests within the architectural discourse and its representation" [Padovano 200 I]. For Tschumi, the architect not only composes forms, but he also brings in his projects "the programmatic and formal interests within the architectural discourse and its representation" [Padovano 200 I].

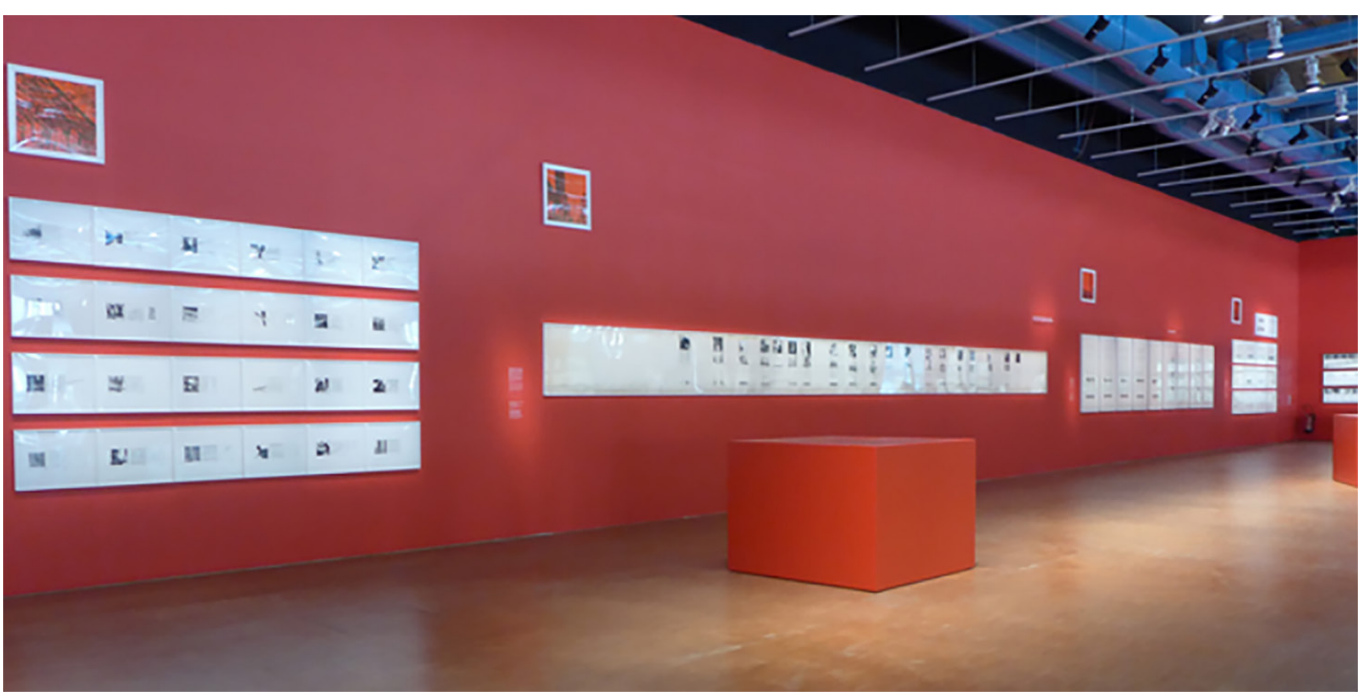


It is not known whether Tschumi had contact with another set of notations developed by the American architect Philip Thiel (1920-20।4), who also questioned the movement of people in spaces. Thiel's notations are focused on phenomenological issues, while Tschumi's notations concentrate on the program. Tschumi's reading of architecture stops it from being just a polarization of form-function, material-concept object, and becomes more than these two poles together. An architectural notation is a physical and conceptual understanding of the built place. This new concept structured like the Elements of Composition, "composed of three levels of representation: that of space, that of movement and that of the event." [Solfa 2008], in an interview with Dwyre [Dwyre 20 I4, p. I 3], Tschumi declares that "there is no architecture without movement." In a very summarized form, according to Saygin [20।8], space corresponds to the architects 'conception, the event to the users' perception, and the movement to their experience.

"although no form of notation [...] can transcribe the great complexity of the architectural phenomenon, the progress of architectural notation is linked to the renewal of both architecture and its associated culture concepts" [Fracalossi 20I2].

Through the tripartition that makes up the term coined by Tschumi he tries to demonstrate that architecture demands a complex reading. Space cannot be just space; it has to

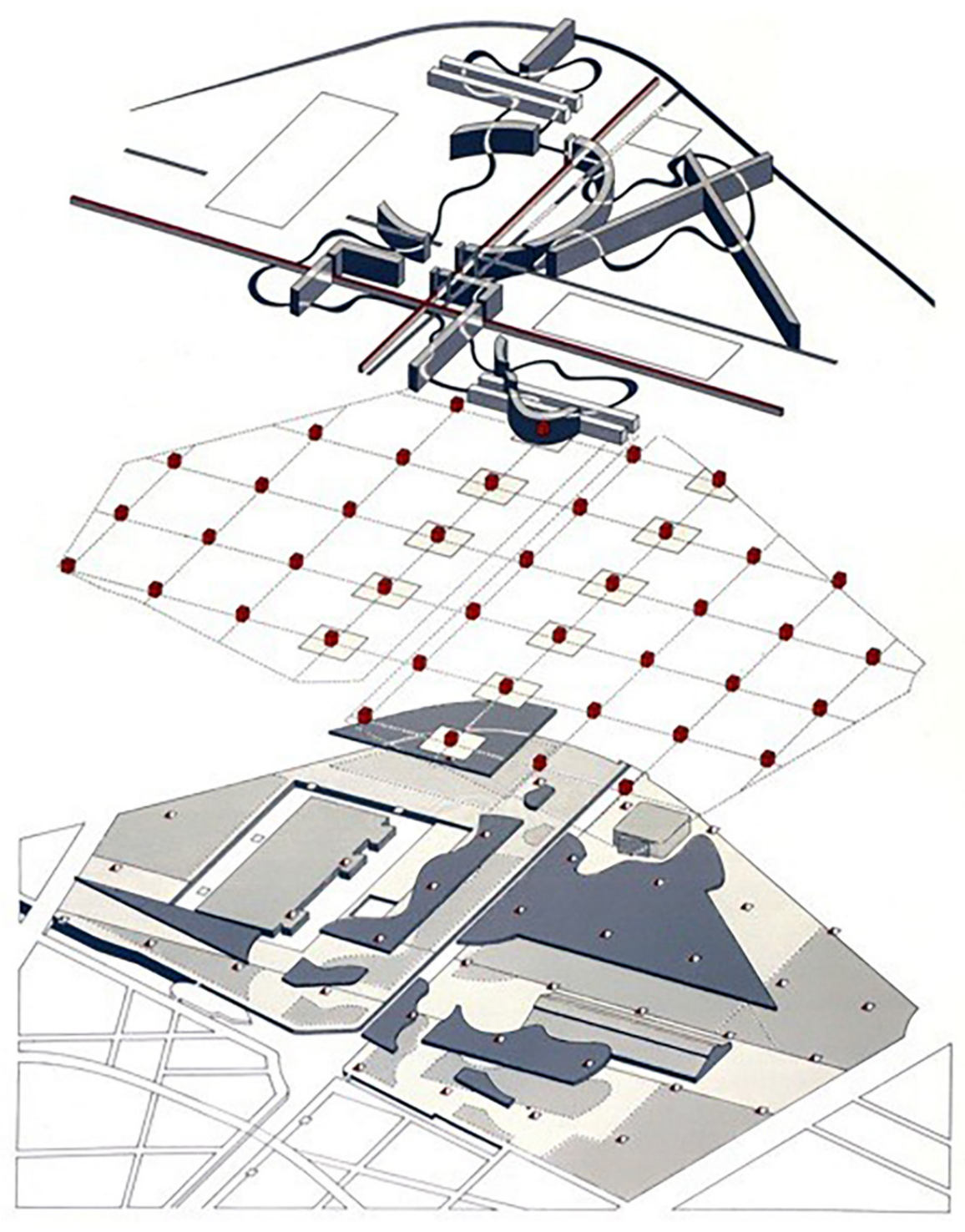


be read together, and mainly, over time. After all, what is space architecturally speaking? In Disjunction and Architeture (1996), this question is answered as follows: "to define space (to make a distinct space) means to 'determine boundaries'" [Tschumi 1996, p. 30]. The objective of the tripartite model that makes up the term is to introduce into architecture "the order of experience, the order of time - movements, intervals, sequences - since everything inevitably intervenes in reading" [Tschumi 1994; Solfa 2008, p. I I].

The notations portraying the events in Manhattan are not architectural drawings; they are not orthogonal projections, nor are they perspective drawings. At the same time, they cannot be categorized as mere fantasies; they transcribe an architectural reality interpreted by the author. The purpose of these so-called transcriptions is to highlight things that are usually removed from conventional architectural representations such as the complicated relationship between spaces and their uses, between objects and events.

In an interview with Alonso [Bernard 2014] Tschmi states that we are prisoners of a part of our biography that we cannot change and that is when we were born and as an inheritance of this permanent part of our history is the moment that the world passes at that moment. At the time, Tschumi was born in 1944 in Laussane, Switzerland, film, and politics were significant, just as the internet is today. The influence of the seventh art is so evident in Tschumi's work that when translating the architectural Notations present in the Manhattan Transcripts, he found, among other products, a 32-foot - $9.75 \mathrm{~m}$ - design representing a walk on 42nd Street in Manhattan (fig. I).

Although The Manhattan Transcripts 'launched' Tschumi academically and theoretically, it was the French park La Villette (fig. 2) that puts it on the world circuit of architects. The competition promoted by the government of France in 1982-1983 envisaged a park where before it had been a large slaughterhouse that operated between the 19th and 20th centuries (Comber 20 I 8). The park that is based on systems established by Tschumi through points, lines, and orthogonal planes, the only winding path according to Guatelli [2017], is "the 'cinematic' path [...] a tribute by Tschumi to the cinema, the art of mo-

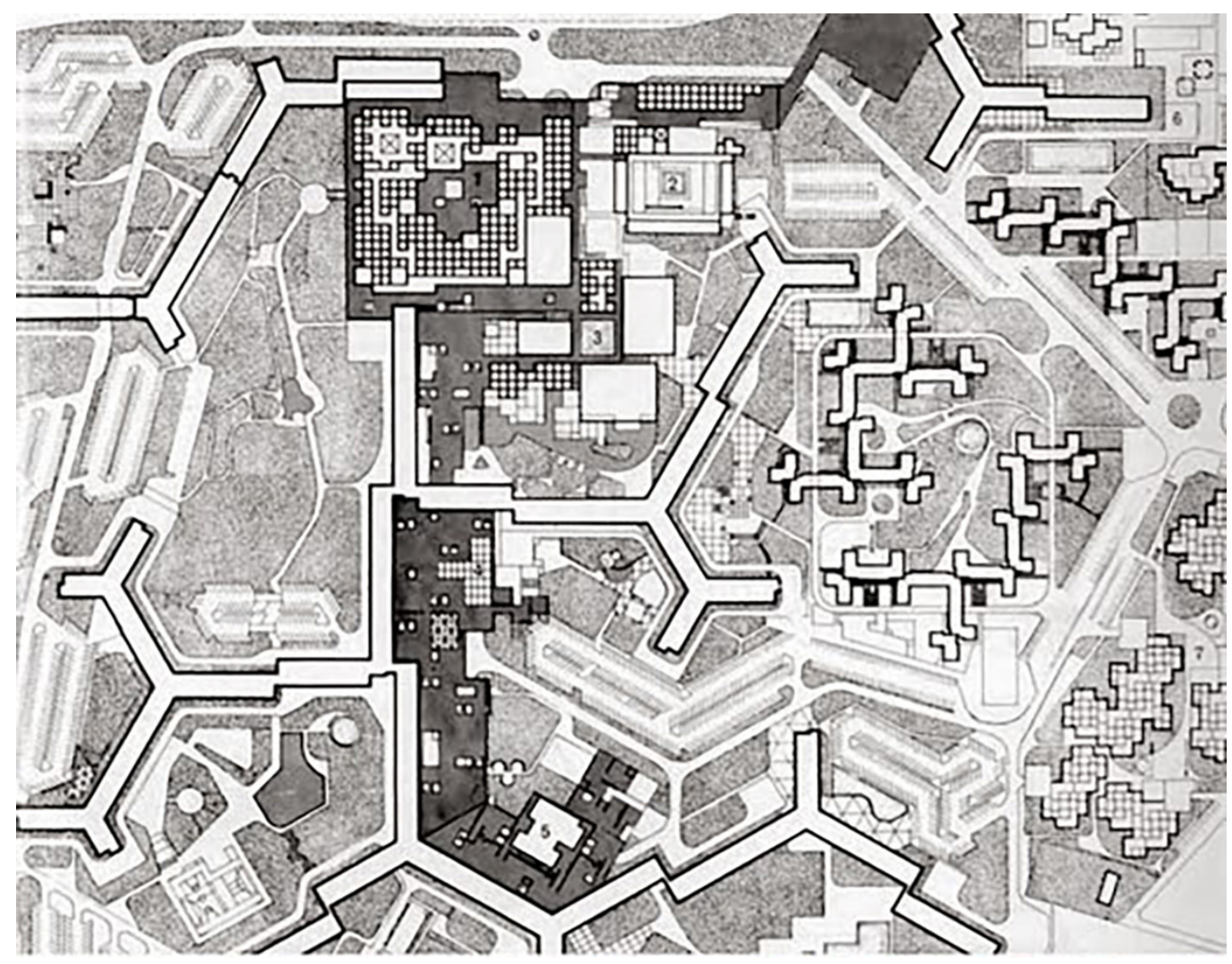


vement". Other influences of the traces elaborated by Bernard that could be identified throughout his career Derek Reddington, Cedric Price, and the three architects who composed the Candilis-Josic-Woods office.

Starting with the last mentioned, the three architects -George Candillis (1913-1995), Shadrach Woods (1923-1973), and Alexis Josic (1921-201 I)- wereTschumi's bosses who interned with them for some time in Paris. Similar to the paths proposed by Tschumi, we can identify two projects by his former chiefs, Le Mirail (1962), located in Toulouse, France (fig. 2).

The project was the subject of a tender and proposed the creation of different densities for a neighborhood of approximately 100,000 inhabitants. The design shows, although much more orthogonal in its buildings, also establishes paths and divisions like the one presented in the contest won by Bernard.

The second reference Cedric Price (1934-2003) also influenced him as a student, if we look at one of Price's most relevant projects known as Fun Place (fig. 4) and the thesis developed by Tschumi (fig. 5) we observe the direct influence the layout of each other. Cedric had at his center the idea of permanent flexibility; for him, buildings should always serve a purpose, and that should never be demolished but modified for new uses. AlthoughTschumi never executed the project presented in his thesis, Cedric's Fun Place has borne fruit and is an evident influence of what today is the George Pompidou Center in Paris.

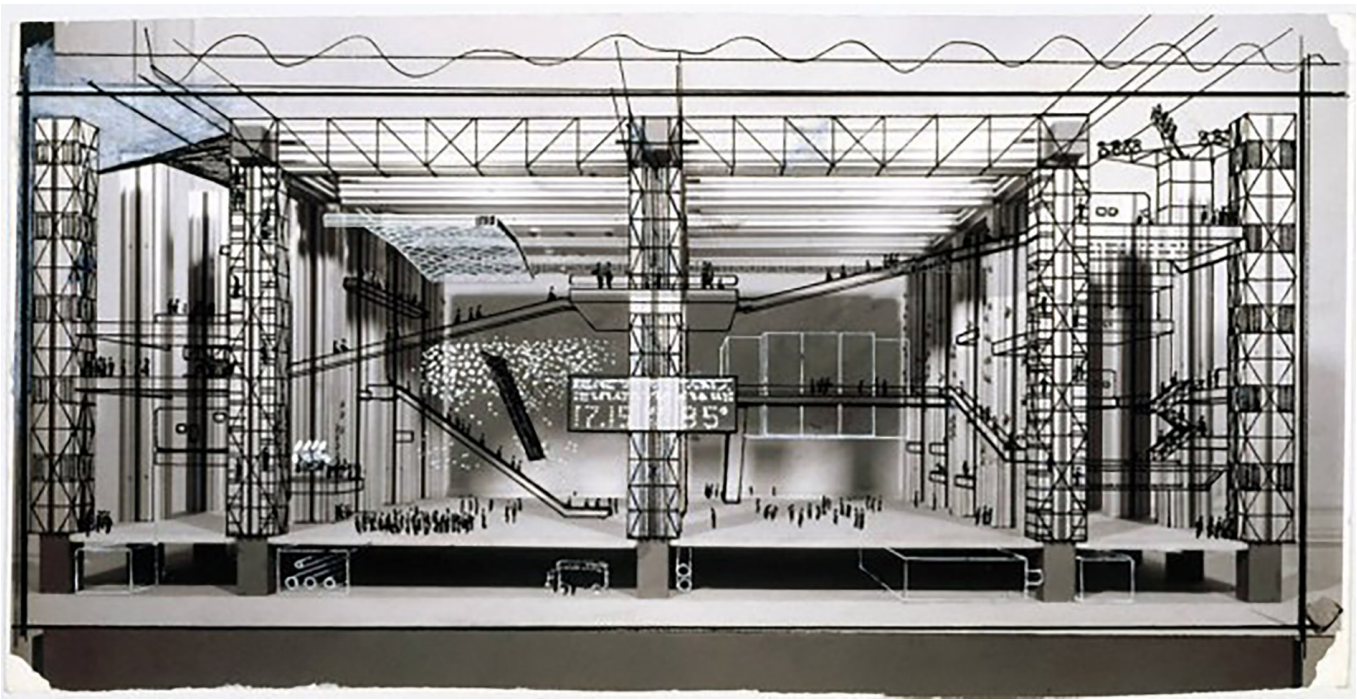

As the last influence listed is someone who influences Tschumi at a later stage of his academic training. Dereck Revington is a recent graduate who participates in the exhibition organized by Tschumi in 1975 in New York called A space: a Thousand Words [Bernard 20 I7]. At the time, guests should choose an image that represented what space for them was and that complemented the information with a thousand words. Revington selects the layout of an abandoned warehouse in London, where he intervenes. Walking around the place, he records the movements, and the paths traveled, generating a definition of the space marked in chalk on the floor (fig. 6). The similarity of what is presented by Revington and the winning project of the Parisian park designed by Tschumi is undeniable. 
Fig. 5. Image of Bernard Tschumi's thesis [Tschumi 2013]

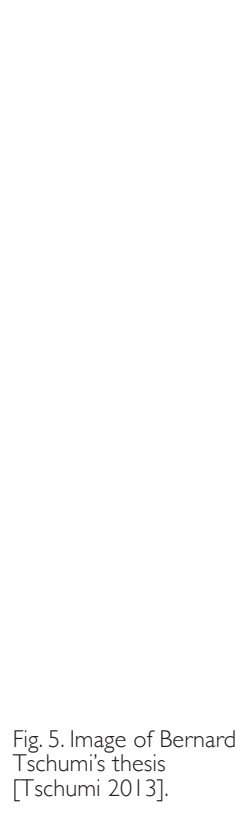

Fig. 6. Floor plan of the movements performed by Dereck Revington [Cook 1983].

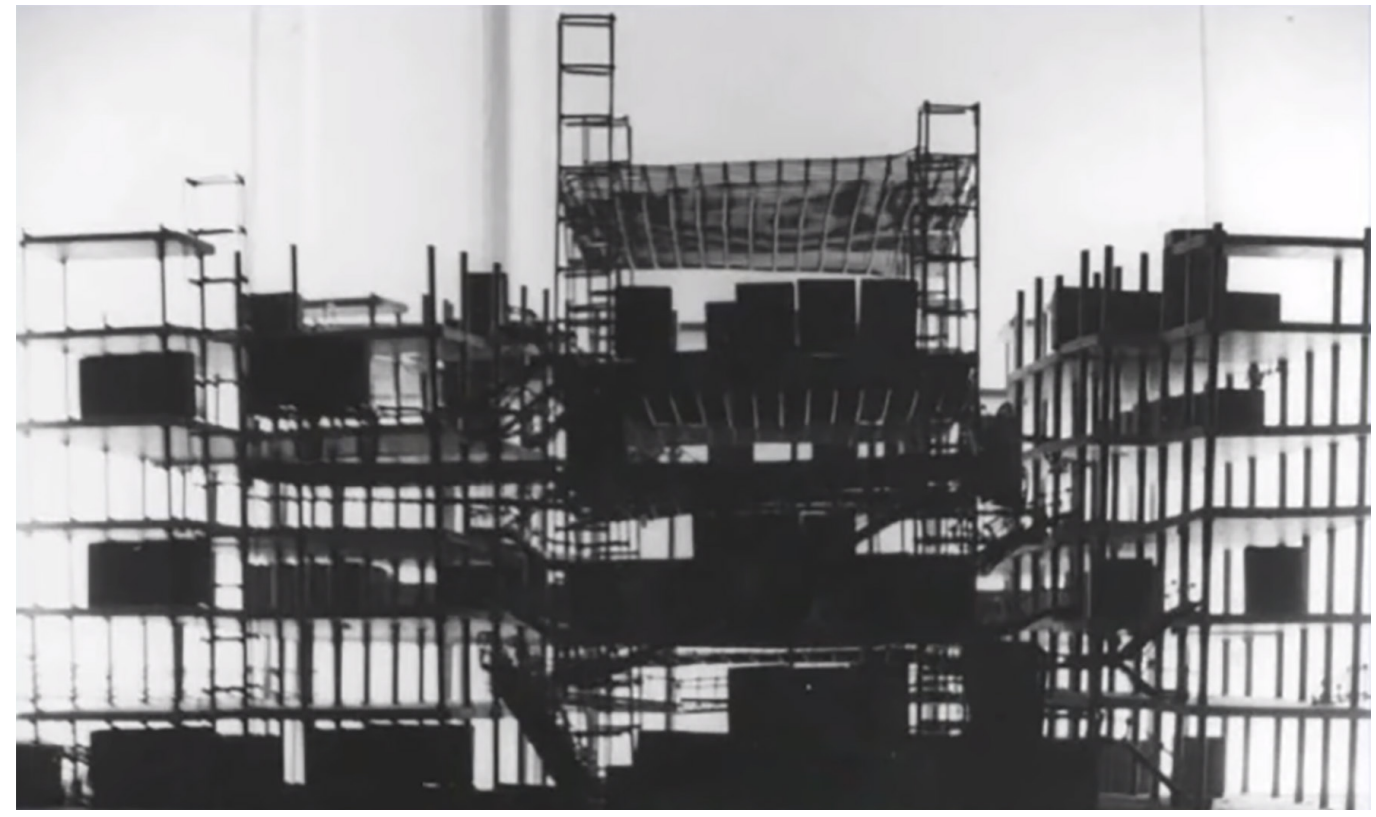

\section{Conclusion}

The history of drawing is intertwined with the history of architecture, in this small period and actors we observe that Bernard allows himself to be influenced by characters who actively contributed to the design to evolve and reinvent itself together with humanity, its demands, and its innovations. Tschumi manages to collect all these sources and turn them into one of the most exciting aspects of contemporary architecture, Architectural Notation, studying the space, its appropriation, and its dynamics through movement and presenting the results through drawings and making a lot of them in La Parque Villette. The graphic fruits of the analysis from the perspective of architectural notation register the movements in such a way that they resemble large film scripts.

It is possible to notice that La Villette also has in its proposals the influences of these three identified characters. The density variation proposed by Candillis, Woods, and Josic can be seen in the distribution of equipment in the park. The adaptability advocated by Price is broadly based on allowing users to enjoy the equipment or, if we agree with Kenneth Michael Hays [Tschumi 2013], the 'events' present in the park. And the transformation of a place into space through appropriation and the path as demonstrated by Revington in a prelude to what would become Architectural Notation. The reinvention of the analysis that the notation proposes rescues drawing in an era where computers have already gained territory, and even today, it continues as an innovative key for reading built spaces.
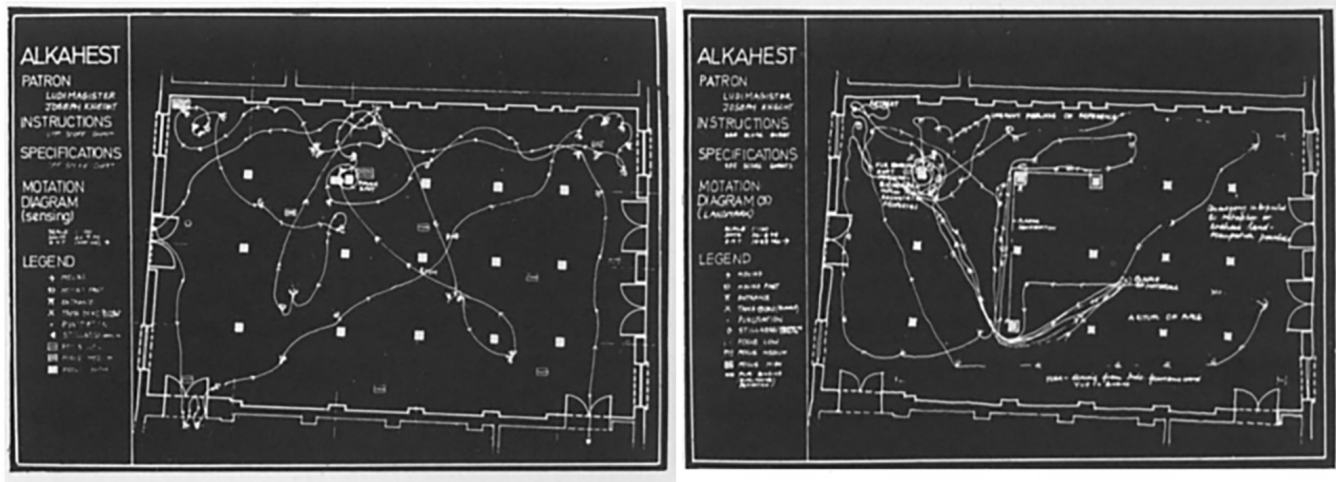


\section{References}

Comberg E. (20 I 8). Como o Parc de la Villette influenciou a maneira como projetamos nossos parques no século XXI [How the Parc de la Villette Kickstarted a New Era for Urban Design] 23 Ago ArchDaily Brasil. (Trad. Libardoni,Vinicius) <https:// www.archdaily.com.br/br/900296/como-o-parc-de-la-villette-influenciou-a-maneira-como-projetamos-nossos-parques-no-seculo-Xxi>

Cook Peter (1983). Strange pavilions of the mind. The Work of Diploma Unit 10, 1973-1983. In AA Files, (4), pp. I02-107: <em www.jstor.org/stable/29543369>

Dwyre Cathryn, Perry Chris \& Tschumi Bernard (2014). Architecture Beyond Architecture. In PAJ: A journal of Performance and Art, 37(I), pp. 8- I5: <https://doi.org/| 0.1 | 62/PAJ__a_0023|>.

Fracalossi Igor (2019). "Disjunções / Bernard Tschumi" 26 Abr 20 I2. ArchDaily Brasil: <https://www.archdaily.com.br/45675/ disjuncoes-bernard-tschumi>.

Glynn Ruairi (2005). Fun Palace - Cedric Price. Interactive Architecture. 19 out 2005: <http://wwwinteractivearchitecture.org/ fun-palace-cedric-price.html. Acessado em 12 jan 2020>.

Graham Foundation (2008). Graham foundation, 2008: <http://www.grahamfoundation.org/grantees/5 I80-bernard-tschumi-concept-and-notation Acesso em 14 fev. 2020>

Guatelli Igor (2017). Edificar parques. $\bigcirc$ [parergonal] Parc de La Villette e o futuro do passado. In A quitextos, São Paulo, ano I 8 , n. 208.01,Vitruvius, set. 2017: <https://www.vitruvius.com.br/revistas/read/arquitextos/|8.208/67/5>

Padovano Bruno Roberto (200 I). Bernard Tschumi. Entrevista, São Paulo, ano 02, n. 008.0I, Vitruvius, out. 200 I:<http://www. vitruvius.com.br/revistas/read/entrevista/02.008/3344>.

Papillault Rémi (2020). Planejamento em seção: <https://planejamentoemsecao.wordpress.com/casos-de-estudo/50s-60s/ le-mirail-candilis/>

Saygin Salgirli (2018). Radicalizing Premodern Space: A Perspective from the Late Medieval Ottoman World. In Radical History Review. I' January 20 I8; 2018 (130), pp. 45-6I. doi: https://doi.org/I0.1215/01636545-42I7889

Solfa Marilia, Serra Richard,Tschumi Bernard (2008). Richard Serra e Bernard Tschumi:.Anais do II Seminário Arte e Cidade: Cultura, memória e contemporaneidade, p. 21, 2008; <https://www.academia.edu/19872921/_Richard_Serra_e Bernard_Tschumi_arte_e_arquitetura_voltadas_para_a_constituição_e_percepção_do_espaço_urbano_?auto=download>.

Souza Abelardo de (20।3). E. Clássicos da Arquitetura: Parc de la Villette / Bernard Tschumi [AD Classics: Parc de la Villette / Bernard Tschumi Architects] 21 Dez 2013. ArchDaily Brasil: <https://www.archdaily.com.br/ |604 I 9/classicos-da-arquitetura-parc-de-la-villette-slash-bernard-tschumi>

Sperling D. Moreno. (FAU/USP). (20I I). Manhattan Transcripts Desdobrado - A Arquitetura Parametrizada pelos Eventos. In Cadernos de pós-graduação em arquitetura e urbanismo, Dezembro 20 I I, p. 809, 20 I l: <https://www.researchgate.net/publication/2363|2458_Manhattan_Transcripts_Desdobrado_-_A_Arquitetura_Parametrizada_pelos_Eventos>.

Tschumi Bernard (1978). Part I of 2. Los Angeles, EUA: Southern California Institute of Architecture, 2017: <https://www. youtube.com/watch? $v=7$ MMIEitAofM>

Tschumi Bernard (1996). Architecture and Disjunction. Cambridge, Massachusets: The MIT Press.

Tschumi Bernard (2013). Palestra proferida na Escola de Graduação em Design da Universidade de Harvard (Massachusetts): $<$ https://www.youtube.com/watch?v=nJ4RIYkJ_v0>

Tschumi Bernard (20|4). Interview. Direção: Phineas Harper.Veneza:The Architectural Review: <https://www.youtube.com/ watch? $=$ Dac_IIP5Dc0>.

\section{Authors}

Luiza Paes de Barros Camara de Lucia Beltramini, Univeraity of São Paulo, luiza.beltramini@usp.br

Paulo César Castral, Univeraity of São Paulo, pcastral@usp.br

To cite this chapter: Paes de Barros Camara de Lucia Beltramini Luiza, Castral César Paulo (2020). As camadas de Tschumi: uma breve análise de influências gráficas de Bernard Tschumi/Tschumi's layers: a brief analysis of Bernard Tschumi's graphic influences. In Arena A., Arena M., Brandolino R.G., Colistra D., Ginex G., Mediati D., Nucifora S., Raffa P. (a cura di). Connettere. Un disegno per annodare e tessere. Atti del $42^{\circ}$ Convegno Internazionale dei Docenti delle Discipline della Rappresentazione/Connecting. Drawing for weaving relationships. Proceedings of the 42 th Internationa Conference of Representation Disciplines Teachers. Milano: FrancoAngeli, pp 7|8-73|. 